\title{
The role of organizational ties managed by practice firms. The case of Perting Ltd
}

\author{
Massimo Bianchi \\ University of Bologna \\ massimo.bianchi@unibo.it \\ Daniele Gualdi \\ University of Bologna \\ gualdi.daniele@gmail.com \\ Laura Tampieri (Corresponding Author) \\ University of Bologna \\ laura.tampieri@unibo.it
}

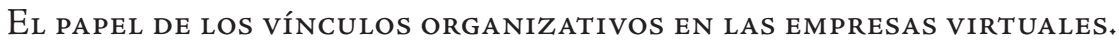
El caso de Perting SRL

Resumen

El artículo analiza los vínculos organizativos recreados en los departamentos o áreas funcionales de Perting LtD, empresa virtual que desde 2001 se ba venido desarrollando en la Universidad de Bolonia. Estos vinculos se analizaron entre dichos departamentos $y$ los profesores/tutores (vinculos educativos), entre los propios departamentos (vinculos operativos internos), $y$ con agentes externos (vinculos operativos externos), durante el primer semestre del curso académico 2016/2017.

Los resultados delatan una cierta estabilidad en la evolución de los vinculos y una prevalencia de vínculos internos. Además, en relación al feedback o tiempo de espera en la respuesta fue menor en las relaciones internas entre los departamentos de Perting que en los contactos externos.

Palabras clave: vinculos organizativos, networking, gestión. 


\begin{abstract}
The paper analyzes the organizational ties created by the functional offices of Perting LtD, the Practice Firm established since 2001 in Bologna University, with teachers / tutors (educational ties), with other offices (operative-internal ties) and external parties (operative-external ties) during the first semester of the academic year 2016/2017.

A certain stability in the evolution of ties and the prevalence of internal ties are outlined. Furthermore, the feedback, measured as waiting time for a response, inside Perting among their functional offices was lower than those related to external networking.
\end{abstract}

Keywords: organizational ties, networking, management. 


\section{Introduction}

The literature appears rich on the subject of networking with a focus on the aspects related to trust (Gossling, 2007), power (Martinez et alii, 2012), embeddedness (Uzzi, 1997), intra organizational and inter organizational ties (Lin, 2002), network dynamics (Ahuja et alii, 2012; Ferriani et alii, 2012), and performance (Gargiulo et alii, 2009; Johannisson and Monsted, 1997).

In addition, a high number of studies have investigated the ties dynamics over the firms' development phases (Hite and Hesterly, 2001; Jack et alii, 2008; Elfring and Hulsink, 2007).

On this concern, the relevance of distinguishing internal (intra-organizational ties) and external ties (inter-organizational ties) in the networking pattern developed by firms over time is highlighted as well by previous research (Eckenbofer and Ersbova, 2011). This distinction is important in understanding how the ties among functional units evolve alongside other external parties.

The orientations underlined by literature on networking in real companies can be validated in the simulated environment of Practice Firms (PFs hereafter), in which the reproduction of business functions needs the building of intraorganizational and inter-organizational ties (Bianchi and Tampieri, 2013).

The PF experience is a didactical methodology that draws on action-oriented (Ceriani, 1996) and practical-based learning (Prince, 2004). It applies the concepts of learning by doing (Amabile and Khaire, 2008) and collaborative learning in a multidisciplinary perspective allowing students to learn and accomplish different operative duties of business management with autonomy, responsibility, and problem solving approaches (Gramlinger, 2004; Jonassen et alii, 1999).

One of the key elements in PF methodology is the establishing of intraorganizational and inter-organizational ties to reproduce networking and relationships among different actors of actual companies. The first refers to the relationships established among functional offices that belong to the internal organizational structure, while inter-organizational ties are those developed with external agents, such as the National Centre of Practice Firms ${ }^{1}$, customers, suppliers, consultants, business partners and projects' University partners.

In addition, in PFs (and generally in the learning context) the educational ties between students and teachers/tutors have to be also considered. The teacher/ tutor has only the role of supporting and supervising the students' work by assigning objectives and transferring basic information or documents that enable the students to accomplish their tasks (Gualdi and Melagranati, 2015)

1 See <http://www.simulimpresa.com/go/>. 
This distinction is relevant and contributes to the separation between the purely formative action of teachers/tutors over students through their support and educational function, and the recreation of strictly operational ties developed both internally (between operational offices of the PF) and externally (between operational offices of the PF and other external agents). Through the implementation of these ties, students gain entrepreneurial and managerial skills that enable them to improve their understanding of business management.

This research focuses on the networking pattern developed in PFs by analyzing the specific case of Perting Ltd (Perting hereafter). Perting is a PF that simulates a company of consulting services and trade of ICT products, which was established in Bologna University Laboratory of Experimental Management under the name of «Simulimpresa»" in 2001, and that has existed ever since. Since its beginning, 887 students have participated, which represent a total of 770 hours of working in connection to the National Centre of Practice Firm and Europen-Pen International Network ${ }^{3}$.

This case analysis contributes to some studies on the subject (Gualdi, 2016, Tampieri, 2013, 2014, 2016 a, b), which are centered on the evolution of network ties over time, in the startup phase, and on the internal and external orientation of functions developed by students.

The purpose of this study is to analyze how networking (expressed by the organizational ties generated between the functional offices, between the functional offices and the teachers/tutors, and between the functional offices and other external agents) and feedback time (expressed by the average number of minutes of waiting for a response) evolved over the experimentation period (October-December 2016) in Perting. Moreover, this study seeks to determine which functional offices were more externally or internally oriented.

The paper is structured with an initial section of theoretical background focused on Practice Firm and the role of networking in this methodology. Subsequently, the methodological framework and the case of Perting were analyzed. Furthermore, the results were presented and discussed. The paper concludes with the practical implications, limitations and future research perspectives.

2 Official study course at Bologna University, Forlì School of Economics, Management and Statistics.

3 See <http://www.penworldwide.org/>. 


\section{Theoretical background and research questions}

\subsection{The methodology of Practice Firm}

The Practice Firm (PF) is an active teaching methodology based on a learning by doing approach that aims to reproduce in a laboratory the functioning of an actual business in aspects related to its organization, environment, relationships and goals (Gualdi, 2016). PFs are set up with key business functions such as administration, personnel, commercial, etc., in which students perform a specific task, with a high degree of closeness to reality (Troudt et alii, 2010; Dessinger, 2007).

The origin of this methodology comes from northern European origin, and afterwards has been diffused worldwide, mainly in high schools and universities. The most important networks linking these training experiences are EuropenPen International ${ }^{4}$, and IVE (Institute for Virtual Enterprise) ${ }^{5}$.

Moving from the classroom to the laboratory, this methodology applies experiential learning where the student learns the business by doing it (Lackeus, 2015; Cope, 2005; Minniti and Bygrave, 2001), acquiring knowledge and developing entrepreneurial skills, abilities and competences (Borgese, 2011; Kiraly, 2011). From this point of view, it is exceeded the «talk and chalk approach» of the topics, encouraging a new way of learning business administration disciplines (Veneziani, 2012; Le Boterf, 2000).

In the business laboratory that the PF recreates, it is possible to rebuild the business layout, set up the equipment allowing students to feel physically their presence in a firm albeit virtual and the way to work within it. The students have to perform all the management operations of a real firm since its startup phase, they must be focused in the production and virtual trade of goods and services, until the cessation of the virtual company activities. In this experience, students must accomplish all legal formalities, tax accounting and mandatory deadlines, using documents, business applications, and communication procedures, commonly used in real life (Tampieri, 2009).

Each student works with other colleagues in a specific office and performs all operations of company management by enabling the virtual exchange of goods and services in a network formed by other national and international PFs (Bianchi et alii, 2014).

4 Non-profit association based in Essen in Germany that includes more than 7,500 companies operating in 43 countries in simulated training systems such as, high schools, professional training courses and universities. 5 It is in NYC (USA), born on the basis of Europen experience in 2002. IVE connects about 140 universities around the world, 2,000 simulated enterprises and an average of 6,000 involved students. 
In the Europen model, experienced within the University, each PF is organized according to educational needs, and with a structure that usually includes a breakdown by departments or operational units represented by offices. In these offices, students perform their work and tasks in rotation, once reached the required skills (Bianchi et alii, 2015). The simulated activity of PFs includes the virtual trade of goods or services, and also consulting activities for other PFs, and in some cases, also for real businesses ${ }^{6}$.

Within the simulation, the composition of training time changes. It exceeds learning linearity based on the succession of theoretical knowledge to be acquired sequentially, switching to a generative learning and to a not preordained application of multi-disciplinary contents, connected to solve problems that are created by business operations (Stanley and Marsden, 2012; Pierce and Jones, 1998). The problems propose changing situations constantly, which arise from the continuous flow of information that comes from business management, and which push students constantly to face complex situations and to reassess the work.

PFs are devoid of real risk, but despite being only plausible, nonetheless it is inspiring. The committed errors are considered «training» in the sense that each mistake accustoms the student to assess their skills differently, and to understand that the attempt to overcome the failure is itself a source of learning. Other features of the PF methodology are: interactivity in the learning process, teamwork and personalization of the training course (Gualdi, 2016).

\subsection{The networking in Practice Firm}

The use of the PF methodology contributes in the relational dimension (Krasniqi et alii, 2011), when students, taking part in the experimentation, establish ties with: 1 ) teachers/tutors (educational ties); 2) students from different operational offices (operative-internal ties) and 3) external agents such as the National Centre of Practice Firm, customers, suppliers, consultants, business partners and projects' University partners (operative-external ties). Such networking takes the form of communication developed in face-to-face encounters, and through the use of information technology, including collaborative platforms and social networks.

The relationships between the functional units (departments and offices) are important as they emphasize teams working where duties and tasks are shared, discussed, developed and solved at different levels. A variety of relationships can

6 For instance, the case of PF at Uniwersytet Ekonomiczny, Wroclaw-Ekonomii, ZarzaDzania I TurystYki di Jelenia Gora that provides accounting consultancy to real local firms. 
be outlined, among the students who work in the same operational unit or office, or among students belonging to different ones. In this complex system of ties, ICTs play a key role allowing student to share work in progress, from informative systems, to intuitive collaboration technology that needs to be part of the normal flow of information (Johns and Gratton, 2013).

Regarding the relationships with teachers/tutors, it is important to outline that for the teacher who coordinates the PF is very important to plan the activities that each department of office must develop in each session, and to organize the exchange of information that will take place among the organizational units, in order to optimize the efficiency of the business structure and to promote student' autonomy.

To this purpose, it is necessary to detect in every session, the different ties developed in the context of the PF, both internal and external ones. In this way, the training path can evaluate the correctness and optimization of procedures carried out, as well as to get an efficient system of internal and external communication. The transactions between PFs have the main purpose of exchanging information and documentation for the virtual transactions of goods and services.

Regarding the external ties, they emerge from the trade of virtual products and services developed by a PF with others at local, national and international levels. In this process, money and financial institutions are fictitious, as they are represented by a National Centre. The Simulimpresa portal is used to simulate these interactions, providing to participants a basis for developing entrepreneurial competences in the field of business management and administration, and also providing a real dimension to the business decisions, documentation, equipped office, and activities (Komarkova et alii, 2015).

\subsection{Research questions}

Based on the theoretical premises, three research questions are proposed:

1) How do different ties in the context of a PF evolve?

To discuss this question, the study considered the number of different ties (educational, operative-internal and operative external) developed over the experimentation period (October - December 2016) in Perting.

2) What are the connections between the different types of ties and the functional offices?

To respond this question, the numbers of the different ties or each functional office in Perting were analyzed, to determine if they were more more externally or internally oriented.

3) How does the feedback time evolve over the experimentation period? 
This issue was related to the average time of feedback (in minutes) in each working session devoted to internal and external networking.

\section{Methodology}

Data were collected through a questionnaire fulfilled by 21 students participating in "Simulimpresa" during the academic course 2016-2017 at Bologna University. The specific subject in which this methodology was implemented started in October 2016 and ended in December 2016. It was developed during 40 hours and comprised 16 working sessions.

The questionnaire was divided into two parts: one related to internal networking and another to external one. With reference to a particular date or working session, each office was asked to indicate with which other offices or external agents (National Centre of Practice Firm, customers, suppliers, consultants, business partners and projects' University partners) had established contacts, offering details on: number, media used for communication (e.g, via e-mail, face to face), feedback (how many minutes had passed before receiving an answer to a specific enquiry), exchanged content in the form of information or document.

The questionnaire was submitted by e-mail to all participants by the tutor during the first working session, with a clear and precise indication on how to complete it. It was fulfilled at the end of each session just to facilitate data accuracy. To ensure the quality of data collection, a mid-course review meeting was held with the tutor to discuss about the questionnaire fulfillment. At the end of the simulation period, the questionnaires were collected by the human resource department staff (one of the internal offices of the PF), who doublechecked for errors and proceeded to the tabulation with the tutor's support.

The functional offices, as shown in Perting' organizational chart (Figure 1), were: web office, international projects office (composed by $\mathrm{RECHT}^{7}, \mathrm{SCAN}^{8}$, BECK ${ }^{9}$ and New Project group), human resources department which counts with an administration office, marketing office, and administration department, composed by management control, fiscal \& treasure, and accounting offices.

7 Project «Regional Joint Master Programme on Tourism in Cultural Heritage for Caspian Area Countries» within ERASMUS + call.

8 Project «Strengthening Students Capacity in Creating Quality Culture in Kazakhstan» within ERASMUS + call.

9 Project «Integrating education with consumer behaviour relevant to energy efficiency and climate change in Russian, Belarusian and Kazakh universities» within ERASMUS + call. 
Figure 1. Perting' organizational chart.

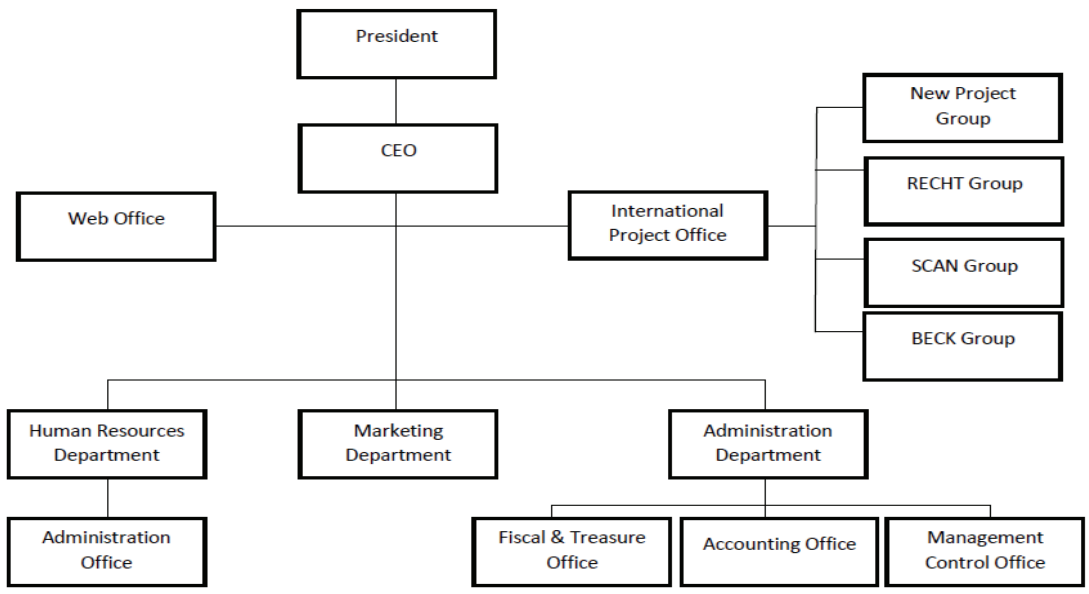

In total, 10 functional offices were analyzed, with an internal composition that varies from 1 to 4 students $^{10}$ (Table 1 ).

Table 1. Perting' functional offices

\begin{tabular}{|l|c|c|}
\hline \multicolumn{1}{|c|}{ Functional Office } & Acronym & $N^{\circ}$ Students \\
\hline Human Resources Department & HRD & 3 \\
\hline Web Office & WO & 1 \\
\hline Fiscal \& Treasure Office & FTO & 2 \\
\hline Accounting Office & AO & 4 \\
\hline Marketing Office & MK & 3 \\
\hline New Project Group & NPG & 1 \\
\hline RECHT Project & RECHTP & 2 \\
\hline SCAN Project & SCANP & 2 \\
\hline BECK Project & BECKP & 2 \\
\hline Management Control Office & MCO & 1 \\
\hline & Total & \\
\hline
\end{tabular}

The items used to analyze the networking ties in Perting were:

1. Number of educational ties between students and teacher/tutor when explanations and clarifications are given to participants enabling them to undergo their assigned tasks.

10 For the analysis purpose the number of students is not considered as a variable. 
2. Number of operative - internal ties based on the contacts among functional offices in performing business activities.

3. Number of operative-external ties between functional offices and external agents, such as the National Centre of Practice Firm, customers, suppliers, consultants, business partners and projects' University partners.

Moreover, the feedback time (measured as the average number of minutes of waiting for a response) was used to evaluate the efficacy of information/ document transfer, in both internal and external networking.

\section{Results}

To respond to the first research question: How do different ties in the context of a PF evolve?, this study considered the number of different ties undergone by Perting' functional offices over the experimentation period (October - December 2016).

The networking pattern of Perting (Figure 2) shows a certain stability of educational and operative-external ties while internal ties follow a rather uneven trend.

During the experimentation period, the educational contacts were 177 . The first working session presented the highest number of contacts (18), higher than the others, because functional offices were assigned to students and to this purpose many requests for clarification among students emerge. This typology of ties was performed by all functional offices in a reasonable way. This means that teacher/tutor had supervised and supported the students in performing activities distributing the time dedicated to them in a balanced way.

In the case of operative-internal ties, the results show a total of 430 contacts (62\% of the total ties, considered all the types). In the first working session, there was no contact between the offices, as each office was interested in their own tasks management. With a total number of 108 contacts, the working session No. 9 was the one with the highest number of internal ties, due to in this section te students presented their tasks and deliverables in the presence of Bec Cooperative Society ${ }^{11}$ representatives. In the last working sessions, a decrease number of contacts was observed, because these sessions were devoted to conclude the tasks assigned to each office.

11 The Practice Firm operating in Parma University since 2014. 
Figure 2. The evolution of educational, operative-internal and operative- external ties.

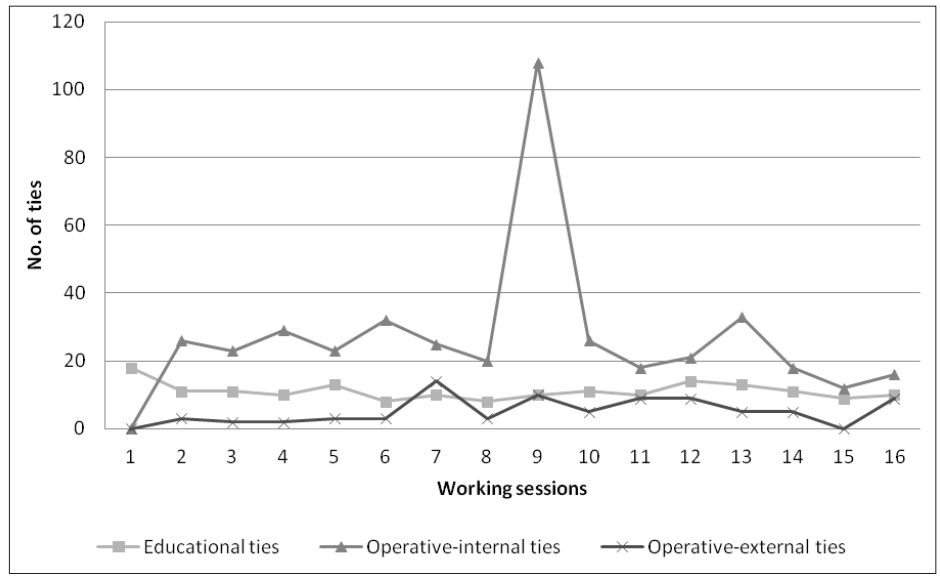

Regarding the external contacts, in total number of 82 ties were developed. The most significant sessions were no. 7 (14 ties), when several functional offices participated in a Skype video conference with the National Technical University «Kharkiv Polytechnic Institute» (Ukraine) in order to present Perting' activities and products; session no. 9 (10 ties), when there was a presentation of Perting, which counted with the participation of Bec Cooperative Society representatives, as previously mentioned; and the last session ( 9 ties), when an international seminar was hold by Prof. Nestor Lazaro of Bilbao University, who presented the Practice Firm methodology at the Basque Country Centre.

Regarding the second question: What are the connections between the different types of ties and the functional offices?, this research analyzed the different ties of each functional office in Perting, to determine which ones were more externally or internally oriented.

As it is shown in Figure 3, HRD was the most internally oriented office, and has the highest number of operative-internal ties (127), followed by MCO (52), FTO (48) and AO (44). This result was justified by the specific tasks of HRD in terms of attendance register updating, signature of job contracts, and personal data collection of all students. HRD can be considered a key position in Perting due to its connections with the rest of functional offices and to the multidisciplinary dimension of the assigned tasks of this office.

Regarding the external networking, $\mathrm{AO}$ was the office most externallyoriented, with 25 ties, motivated by its connection to a consultant, expert in software management who trained students in the initial working sessions. NPG, RECHTP, SCANP and BECKP offices were mostly focused on the preparation of international projects, they do not have the mission of establishing 
the consortium but were in charge of preparing administrative, financial and scientific conditions of these international collaborations. The external contacts of these offices were basically developed by Skype video conferences with the National Technical University «Kharkiv Polytechnic Institute» (Ukraine) and the University of Bilbao.

Figure 3. The number of different ties for each functional office.

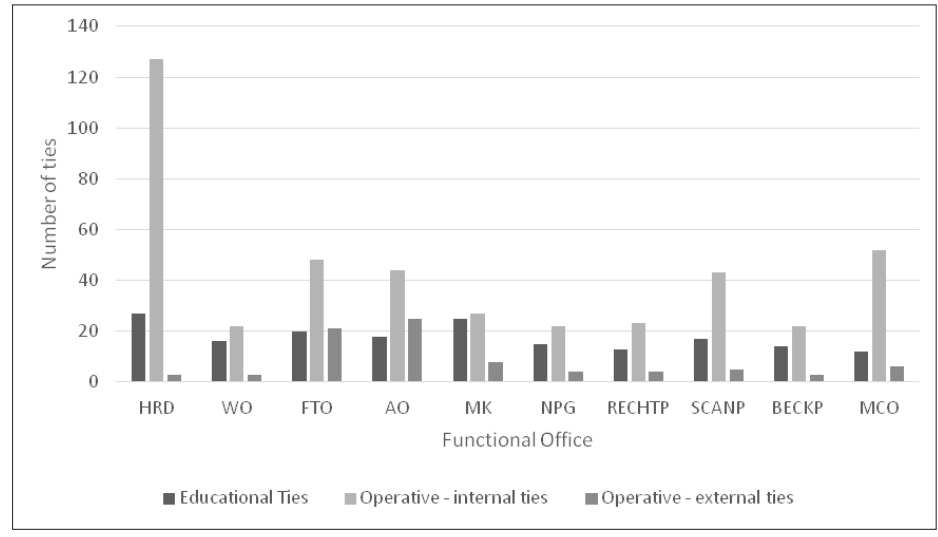

Regarding the third research question: How does the feedback time evolve over the experimentation period?, this study investigated the average feedback time (in minutes) devoted in each working session to internal and external networking.

The results show that there were two sessions with deserve a special mention. The working session no. 2 , when the roles and tasks were distributed among the different functional offices, which justifies a higher feedback time (21.7 minutes). Also, session no. 6 (32.4 minutes) was characterized by a higher waiting time, which occurred between two offices $(\mathrm{AO}$ and $\mathrm{MCO}$ ) as a result of the monthly budget drafting.

At the external level, the working session no. 11 (53.1 minutes) showed the higher waiting time due to the late communication of a supplier and two requests for payment. Finally, also session no. 14 (30.1 minutes) showed an enhanced feedback time due to a transport request made by a supplier.

The average feedback time in internal links was 7 minutes, while the average feedback time of external ties was 13 minutes.

These results have to be related to the media used in the communication (e.g. via e-mail, face to face). In internal networking, the most used media were: faceto-face (93\%), e-mail (6\%) and telephone (1\%); while in the case of external ties, the most frequent media were e-mail ( $56 \%$ ) followed by face-to-face (22\%) and Skype (22\%). 
Figure 4. The feedback time in internal and external networking.

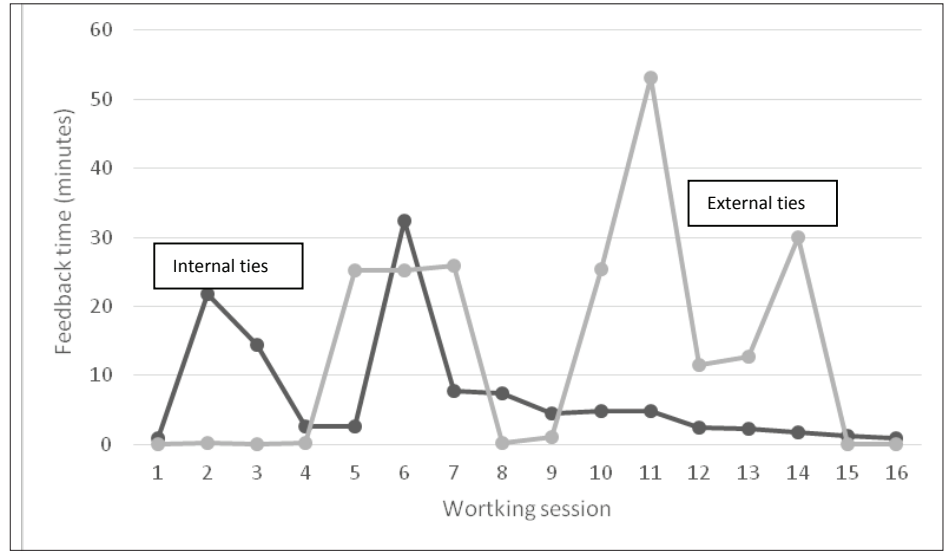

Therefore, the feedback time referred to internal networking was lower than the external one as internal ties were mostly based on face-to-face, which enabled fast transfer of information and documentation. Instead, external ties were mostly performed by e-mail that needed more time than face-to-face for getting responses.

\section{Discussion and conclusion}

The analysis carried out highlights the complex pattern of ties recreated within Perting. This relational dimension represents a key element in PF methodology, as students continually interact with teachers/tutors, with other colleagues belonging to the same or to other functional offices and with external agents.

More specifically, our study highlighted a certain stability of educational and operative-external ties while internal ties followed a rather uneven trend. Moreover, the prevalence of internal ties, compared to external ones and to those maintained with the teachers/tutors, was outlined. Some functional offices (as HRD and MCO) were more internally oriented than others, due to their assigned tasks. Finally, this research also pointed out that the average feedback time of internal ties within Perting was lower than the feedback time of external networking.

This study contributes to previous research on the effectiveness of PFs, which constitutes a research line that needs more contributions about the real utility of this typology of educational methodology to foster internal and external networking. 
Furthermore, the findings could help teachers/tutors to improve the further application of PF methodology, enabling the enhancement of internal and external networking.

Through PF methodology each student not only had the opportunity to take a leading role within their office and to perform the required tasks, but also to achieve objectives together with other colleagues, to interact with different functional offices and external agents, and to develop managerial and entrepreneurial skills.

Among the skills developed using this methodology based on simulation, the most relevant ones for students are the capacity to learn, capacity to adapt to new situations, problem-solving and teamwork. These results, supported by other studies (Fu et alii, 2009; Zantow et alii, 2005), address the focus on the complexity of the firm, the effective job placement and the current challenges of simulating the working world (Fitó-Bertrán et alii, 2015). Regarding the specific skills, the processing and analysis of financial information, planning of management projects, budget control, human resources management, and financial statements preparation are the most relevant (Fitó-Bertrán et alii, 2014, 2015).

This study presents nevertheless some important limitations: first, the reduced sample makes difficult to generalize the results. More data would be necessary to determine stronger conclusions. Second, it would be relevant to consider the number of students as a research item. Finally, the comparison among PF and other e-learning methodologies, like business games and business cases, would be adequate to determine their contribution to new learning models. All these perspectives constitute relevant research streams to be developed in the future. 


\section{References}

Ahuja, G.; Soda, G. and Zaheer, A. (2012) «The Genesis and Dynamics of Organizational Networks», Organization Science, 23 (2): 434-48.

Аmabile, T. and Khaire, M. (2008) Creativity and the role of the leader, Boston, MA: Harvard Business School Publishing.

Bianchi, M. and Tampieri, L. (2013) «Effects of Networking Activities by Internet on the Creation of a Business Network: Experimental Results of Simulimpresa Laboratory». In Spagnolettr, P. (ed.) Organizational Change and Information Systems. Working and Living Together in New Ways, Berlin Heidelberg. Springer, 119-127.

Bianchi, M.; Gualdi, D. and Tampieri, L. (2014) «The laboratory for enterprise simulation in Forlì and the performance of Perting Ltd. 20012012». In Bianchi, M.; Baseska, M.; Ngo Mai, S.; Tampieri, L. and Verges, J. (eds.) Beyond the Horizon of Tempus Projects. Theory and Practice of Project management. Cesena. Società Editrice Il Ponte Vecchio, 235-241.

Bianchi, M.; Hernández-Lara, A.B. and Gualdi, D. (2015) «The contribution of virtual enterprises to competence-based learning: An assessment from the students' perspective», Technology, Innovation and Education Journal, 1(4): 1-16.

Borgese, A. (2011) «Virtual enterprise: transforming entrepreneurship education», Journal of Instructional Pedagogies: 1-8

Ceriani, A. (1996) La simulazione nei processi formativi. Un metodo per un pensiero creative progettuale. Milano, Franco Angeli.

Cope, J. (2005) «Toward a Dynamic Learning Perspective of Entrepreneurship», Entrepreneurship Theory and Practice, 29: 373-397.

Dessinger, T. (2007) «Making schools practical Practice firms and their function in the full-time vocational school system in Germany», Education + Training, 49(5): 364-379.

Eckenbofer, E. and Ersbova, M. (2011) «Organizational culture as the driver of dense intra-organizational networks», Journal of Competitiveness 2: 28- 42. Elfring, T. and Hulsink, W. (2007) «Networking by Entrepreneurs: Patterns of Tie-Formation in Emerging Organizations», Organization Studies 28 (12): 1849-1872.

Ferriani, S.; Fonti, F. and Corrado, R. (2012) «The social and economic bases of network multiplexity: exploring the emergence of multiplex ties», Strategic organization 11(1): 7-34. 
Fitó-Bertrán, A.; Hernández-Lara, A.B. and Serradell-López, E. (2014) «Comparing student competences in a face-to-face and online business game», Computers in Human Behavior 30ः 452-459.

Fitó-Bertrán, A.; Hernández-Lara, A.B. and Serradell-López, E. (2015) "The effect of competences on learning results: an educational experience with a business simulator», Computers in Human Behavior 51: 910-914.

Fu, F.-L*; Su, R.-C. and Yu, S.-C. (2009) «EGameFlowः a scale to measure learners' enjoyment of e-learning games», Computer Education, 52:101-112 Gargiulo, M.; Ertug, G. and Galunic, C. (2009) «The Two Faces of Control: Network Closure and Individual Performance among Knowledge Workers», Administrative Science Quarterly, 54: 299-333.

Gossling, T. (2007) «Proximity, trust and morality in networks», European Planning Studies, 12(5): 675-689.

Gramlinger, F. (2004) «The Advantages and Disadvantages of Learning and Teaching in a Practice Firm». In Mulder, R.H. and Sloane, P.F.E. (eds.) New Approaches to Vocational Education in Europe: the construction of complex learning-teaching arrangements, Symposium Books, Oxford, 81-90.

Gualdi, D. and Melagranati, F. (2015) «Metodologie innovative nell'accounting education. La simulazione d'impresa. Indagine sulle motivazioni e aspettative degli studenti universitari di Forlì e Parma», Quaderni DEM, 4:1-25.

Gualdi, D. (2016) Manuale di Simulazione di Impresa, Cesena: Società Editrice Il Ponte Vecchio.

Hite, J.M. and Hesterly, W.S. (2001) «The Evolution of Firm Networks: From Emergence to Early Growth of the Firm», Strategic Management Journal, 22(3): 275-286.

Jack, S.L.; Drakopoulou, D.S. and Anderson, A.R. (2008) «Change and the Development of Entrepreneurial Networks over time: Processual Perspective», Entrepreneurship and Regional Development, 20, 125-159.

Johannisson, B. and Mønsted, M. (1997) «Contextualizing Entrepreneurial Networking», International Journal of Management and Organization Fall, 27: 109-137.

Johns, T. and Gratton, L. (2013) «The third wave of virtual work», Harvard Business Review, 4:20-27.

Jonassen, D.H.; Peck, K.L. and Wilson, B.G. (1999) Learning with Technology: A Constructivist Perspective. New York: Merrill/Prentice-Hall. 
Kiraly, D. (2011) A social constructivist approach to translator education: Empowerment from theory to practice. USA: Routledge.

Komarkova, I.; Conrads, J. and Collado, A. (2015) «Entrepreneurship Competence: an overview of existing concepts, policies and initiatives», REPORT EUR 27423 EN, European Commission, 268-303.

Krasniqi, F,; Xhelili, T.R., and Pula, J. (2011) «The role of practice firms in preparing youth for the labor market in Kosovo», Asian Journal of Business and Management Sciences, 1:122-134.

LACKeus, M. (2015) Entrepreneurship in education - what, why when, how, Entrepreneurship 360 Background paper. <http://www.oecd.org/cfe/leed/ BGP_Entrepreneurship-in-Education.pdf.>, p. 26, accessed 1 July 2015

Le Boterf, G. (2000) Compétence et navigation professionnelle. Paris: Éditions d'Organisation.

LiN, Z. (2002) «The dynamics of inter-organizational ties during crises: empirical evidence and computional analysis», Simulation Modelling Practice and Theory, $10: 387-415$.

Martinez, A.; Kane, R.E.; Ferris, G.R. and Brooks, D.C. (2012) «Power in leader-follower work relationships», Journal of Leadership E Organizational Studies, 19(2): 142-151.

Minniti, M. and Bygrave, W. (2001) «A dynamic model of entrepreneurial learning», Entrepreneurship Theory and Practice, 25: 5-16.

Pierce, J. and Jones, B.F. (1998) «Problem-based learning: Learning and teaching in the context of problems». In Sherman, M. (ed.) Contextual teaching and learning: Preparing Teachers to enhance student success in and beyond school. Information Series No. 376. Ohio: Ohio State University College, 75-106.

Prince, M. (2004) «Does Active Learning Work? A Review of the Research», Journal of Engineering Education, 93(3): 223-231.

Stanley, T. and Marsden, S. (2012) «Problem based-learning: Does accounting education need it?" ", Journal of Accounting Education, 30: 267-289.

Tampieri, L. (2009) Simulazione in Second Life e business virtuale nello start up d'impresa del sistema moda. Bologna: CLUEB

TAmpieri, L. (2013) «The networkingapproach applied in Practice Firms through internet. The case of Perting Ltd». X Conference of the Italian Chapter of AIS Empowering society through digital innovations, 14 December, Milan, Italy. TAmpieri, L. (2014) «The Network of ties in practice firm for the education to entrepreneurship. The case of Perting Ltd», Procedia-Social and Behavioral Journal, 116:1073-1082. 
TAmpieri, L. (2016a) «The role of Simulimpresa in international projects on Resilience Management». In TAmpieri, L. (ed.) Resilience Management and Renewable Energy Processes. Cesena. Società editrice Il Ponte Vecchio, 135161.

TAmpieri, L. (2016b) «La Simulimpresa nei progetti internazionali ed il contributo alla ricerca sulle reti organizzative». In Gualdi, D. (ed.) Manuale di Simulazione di Impresa, Cesena. Società editrice Il Ponte Vecchio, 223-244

Troudt, E.; Winkler, C.; Audant, B. and Schulman, S. (2010) «The Engineering Virtual Enterprise: A Framework for Soft and Entrepreneurial Skills Education». In 3rd International Multi-Conference on Engineering and Technological Innovation Conference Proceedings IMETI, 2010, 1-6.

Uzzi, B. (1997) «Social structure and competition in interfirm networks: the paradox of embeddedness», Administrative Science Quarterly, 42:35-67.

Veneziani, M. (2012) L'Accounting Education: Osservazioni preliminari sul caso italiano. Milano: Franco Angeli.

Zantow, K.; Knowlton, D.S. and Sharp, D.C. (2005) «More than fun and games: reconsidering the virtues of strategic management simulations», Academy management learning education, 4:451-458. 